\title{
Crisis and Reform Direction of WTO Appellate Body
}

\author{
Yining Yang ${ }^{1, *}$
}

\author{
${ }^{1}$ Pavillon Maximilien-Caron 3101, Faculty of Law, University of Montreal, Montreal, Quebec, H3T 1J7, \\ Canada \\ "Corresponding author. Email: yining-yang@outlook.com
}

\begin{abstract}
As the final decision-making body for the settlement of trade disputes, the WTO Appellate Body is known as the "jewel in the crown". However, since 2019, the Appellate Body has been locked out due to insufficient members. The current situation of the Appellate Body urgently needs corresponding reform plans. Based on the analysis of the development process and basic characteristics of the Appellate Body, this article clarifies the main drawbacks that appear in its operation and analyzes the current challenges it faces. The author believes that the resumption of the WTO Appellate Body needs to solve the existing institutional problems. As a temporary arrangement, MPIA, short for Multi-Party Interim Appeal Arbitration Arrangement, cannot completely replace the Appellate Body. Therefore, member states must reach a consensus as soon as possible to maintain the stability of the multilateral trading system and the prosperity of the world economy.
\end{abstract}

Keywords: WTO dispute settlement mechanism, Crisis of Appellate Body, Reform of Appellate Body, Alternative dispute resolution mechanism(ADR).

\section{INTRODUCTION}

In December 2019, WTO Director-General Roberto Azevêdo officially announced that the Appellate Body ceased operation[1]. Appellate Body, once "jewel in the crown", seems to lost its brilliance since then. People question whether this means the revival of unilateralism and trade protectionism. With the development of the international economy and the increasingly frequent trade exchanges, the WTO Appellate Body are facing more complex international disputes. Through literature research and case studies, this article attempts to clarify the current dilemma of the WTO Appellate Body, explore the specific reasons behind it, and clarify how to improve the international trade dispute resolution mechanism in the future become important issues. These require all WTO members to anticipate the consequences and reconstruct the blueprint for the future.

\section{OVERVIEW OF WTO APPELLATE BODY}

The WTO Appellate Body was established on the basis of Understanding on Rules and Procedures Governing the Settlement of Disputes (DSU). When General Agreement on Tariffs and Trade (GATT) was applied, although panel procedures have resolved disputes between members to a certain extent, there are still problems. For example, different interpretations of WTO regulations, lack of authoritative application of law, vague handling of principled issues, and low efficiency in case handling[2]. Subsequently, when the members established the WTO, they further improved the dispute settlement mechanism and the Appellate Body came into being.

The Appellate Body is responsible for hearing the disapproval opinions of the parties on the panel report. The Appellate Body will make a ruling report and once the ruling report is approved by the Dispute Settlement Body (DSB), it has legal effect. Therefore, the Appellate Body is both political and judicial. As its establishment is conducive to enhancing 
understanding and clarification of WTO agreements, it gradually become a core factor in the security and predictability of the world trading system[3].

However, as the international trade situation has become increasingly complex, the Appellate Body is also facing unprecedented difficulties. The first issue is the selection of judges. The number of judges continues to decrease as the member states have not yet reached a consensus on the selection and appointment. On November 30, 2020, the last judge of the Appellate Body officially expired and resigned. At this point, all judges left their posts and the Appellate Body ceased operation. The second issue is the scope and time limit of the trial. Some WTO members expressed dissatisfaction with the ultra vires review of the Appellate Body. They believe that such behavior will arbitrarily weaken the rights and increase the obligations of WTO members. At the same time, in recent years, most of the cases handled by the Appellate Body have exceeded the maximum 90-day period. Finally, the issue of legal effect of appellate body's reports. Some member states believe that the Appellate Body included unrelated rulings in the report. This led to the chaotic effect of the previous ruling [4].

The current Appellate Body "exists in name only." This has plunged the settlement of international trade disputes into a more complicated situation. It is difficult to ask the respondent to give up its right of appeal in advance because in few cases both parties to the dispute agree that they have the same probability of winning the case. If one party to the dispute continues to appeal the panel report, the case will be placed in a pending situation. Winning but weaker countries will face rulings that are difficult to take effect and lack the ability to take trade retaliation. Losing but stronger countries will seize the opportunity to negotiate. Comparable countries will start a trade war. If member states find another way to resolve trade disputes, the authority and stability of the WTO will be questioned[5]. The member states will once again return to a poweroriented trade dispute resolution mechanism, and the "Spaghetti bowl " kind regulations will return.

Appellate Body reflects the common vision of the members to maintain fair and stable multilateral trade. Compared with other dispute resolution mechanisms, it has advantages in professionalism and authority. The lockout of the Appellate Body not only means that it can no longer make binding rulings on trade disputes, but also means that the outcome of existing trade disputes is uncertain.

\section{DILEMMA OF WTO APPELLATE BODY}

\subsection{Selection of Members}

The biggest crisis is that the Appellate Body has not yet completed the selection of members. This hinders the normal operation and brings systemic risks to the entire WTO. There are two reasons for the current situation: the unclear qualification requirements of the candidates and the voting mechanism of the member states.

First, according to Article 17 of the DSU, members of the Appellate Body should meet some requirements. Candidates must possess expertise in law, diplomacy, international economics, and trade, not affiliated with any government and will not accept instructions from others. Selected members should also broadly represent all WTO members states. Although the above regulations indicate the abilities that candidates should possess, they are mostly in principle and the regulations are not detailed. As the number of cases continues to increase, vague regulations will not be able to guide and regulate the actual selection work.

Secondly, principle of unanimity is making the selection of members long and difficult. The members of the Appellate Body should be appointed by DSB, and DSB implements a consensus voting system for passing proposals. This means that as long as any WTO member state disagrees with the appointment proposal, the selection of members cannot be completed. This voting method can protect the rights and interests of each member when there are fewer members, and achieve fairness in the greatest sense. However, as the number of WTO members continues to increase, the continued application of this principle will cause a deadlock in decision-making. This is inconsistent with the original intention of member states to improve the efficiency of the appellate body. For a long time, how to select members of Appellate Body will become a constant discussion issue in the country, and members with small trade volume and weaker competitiveness will not be able to use dispute settlement methods to protect their legitimate rights and interests, and they will face the ending of being gradually marginalized[6].

\subsection{Scope of Review}

For members of the Appellate Body, how to determine the scope of review is the first difficult problem. According to Article 17 of the DSU, the 
scope of review by the Appellate Body is limited to the legal part of the panel report, including law application and legal interpretation.

The above rules seem clear, but in practice the factual part and the legal part are often difficult to distinguish. Generally speaking, the case trial process is to summarize facts, clarify issues, analyze, and draw conclusions. However, the distinction between legal issues and factual issues is quite controversial in the judicial systems. There is not only one standard of division between the two. Under customary law, legal issues are usually related to applicable rules and standards, while factual issues involve potential affairs or events. For example, in an anti-subsidy case, the court not only needs to judge whether there is a subsidy, but also whether the evidence is legal and sufficient. At this time, it is difficult to distinguish whether the determination of countervailing subsidy belongs to the category of factual issues or legal issues.

WTO involves many trade fields, so the disputes arising therefrom are also numerous and complicated. The immutable and highly generalized judgment criteria cannot resolve all the distinction disputes in practice. Solving the problem of mixed facts and laws is already a difficult task for the courts[7].Despite the efforts of the Appellate Body in rule-making and judicial practice, the relevant provisions of the DSU have limitations and cannot cover all the criteria for distinguishing between factual issues and legal issues.

\subsection{Report of the Appellate Body}

The Appellate Body's report was challenged by some member states. The report issued by the Appellate Body shall include the results and reasons of the ruling. Since the WTO is an international organization, there are often gaps in the domestic laws of its member states.

Appellate Body often quote past rulings in similar cases in their reports. Common law countries recognize case law, which gives judges a kind of lawmaking power. In contrast, non-common law members consider this behavior of judges to be a process of reasoning. In contrast, the precedents in the common law system belong to the law, while in the civil law system are not. In general international law, the rulings of international dispute settlement agencies are not treated as precedents, because the specific circumstances and legal issues of each case are not exactly the same[8]. However, the WTO did not clarify the legal effect of the Appellate Body's precedent, which caused confusion.

\section{AN ALTERNATIVE INSTITUTION: MPIA}

In April 2020, 17 member states notified the establishment of Multi-Party Interim Appeal Arbitration Arrangement (MPIA). According to Article 25 of the DSU, it will temporarily replace the Appellate Body in hearing the panel report. This is to deal with the lockout of the WTO Appellate Body and ensure the normal operation of international economic and trade under the spread of COVID-19. In July 2020, MPIA concluded the selection of arbitrators. As of May 2021, 23 WTO member states have joined MPIA, including important trading countries such as the European Union and China[10].

MPIA integrates the characteristics of arbitration and litigation procedures. First, MPIA takes a prudent attitude to ensure the smooth review of panel reports. For example, if both parties in the dispute intend to initiate an appeal arbitration procedure, the panel can be required to notify the report release time in advance; for the same dispute, the appeal arbitration procedure and the panel procedure cannot be carried out at the same time. Secondly, for the selection of arbitrators, MPIA did not adopt the general commercial arbitration regulations, but basically inherited the relevant regulations of DSU, and made certain adjustments based on practice. For example, the number of arbitrators is ten, and all arbitrators have sufficient theoretical knowledge and practical experience. When reviewing a case, the arbitrator is not appointed by the parties in dispute, but three arbitrators are randomly selected from the list to form an arbitration tribunal. Finally, with regard to arbitration procedures and decision-making mechanisms, MPIA has made certain adjustments on the basis of WTO Appellate Body procedures. For example, to ensure the stability and predictability of the arbitration award, the arbitrator should consult with other members in advance. The arbitration tribunal shall determine the rights and obligations of the disputing parties in strict accordance with the agreement, and the award cannot increase or detract from the rights and obligations of the member states[11].

To a certain extent, MPIA can solve the current problems faced by the WTO Appellate Body, and it also reflects member states' vision for the reform of the WTO Appellate Body. For example, the control of the scope of review, the extension of the review period with the consent of the parties to the dispute, streamlining the application of procedures, and increasing the power of the arbitral tribunal to suggest the scope of appeals. This not only improves 
the efficiency of arbitration, but also partially responds to the current problems encountered by the WTO Appellate Body. It can be described as an innovative and developmental reform consideration.

However, MPIA still has limitations. MPIA still did not mention whether the arbitral tribunal's ruling should take into account the previously adopted Appellate Body's report, and whether it is necessary to provide sufficient reasons and explanations when making different interpretations. This will still cause some member states to doubt the "precedent effect" of the Appellate Body's report. In addition, MPIA also brings new issues. Some major trading nations have not yet joined MPIA. If a dispute occurs, member states still cannot appeal. In addition, the funding source of MPIA is also an important issue[12].

\section{DEALING WITH THE DILEMMA OF THE APPELLATE BODY}

\subsection{Selecting Members to Meet Actual Needs}

With regard to the selection of members of the Appellate Body, the number of members can be appropriately increased or the term of office can be extended. In addition, DSU should further clarify the requirements for the selection of members, or change the voting method from consensus to majority approval.

Judging from the practice of the Appellate Body over the years, the current seven members of the Appellate Body can no longer meet the needs of case trials. MPIA sets the number of arbitrators at 10. At the same time, the DSU did not make clear about conditions and procedures for renewal at the end of the first term of the members. Therefore, whether it is to increase the number of members or extend their single terms, it will reduce the work and the uncertainty. Members can arrange their work schedules reasonably[9].

In addition, the DSU should clarify the qualification requirements for the selection of members of the Appellate Body. Although MPIA clarifies that the selection of arbitrators should meet the overall balance, it only makes vague requirements in terms of authority and expertise. This may still cause member states to waste a lot of time in the selection. Therefore, dividing the selection area according to the source of the dispute, and clarifying the number of judges selected in the area could further ensure that the members of the Appellate Body are broadly representative. This will also mobilize the enthusiasm of legal practitioners from developing countries and new member states.

Finally, the consensus voting method is debatable. MPIA still adopts an unanimous approach to appoint arbitrators, but this is partly because of the temporary nature of this institution and that it does not yet include all WTO members. Using the majority voting method, on the one hand, it can relatively maintain the authority of the Appellate Body, and on the other hand, it can reflect the majority consensus of the members and ensure that the Appellate Body can always operate normally, instead of being trapped in the quagmire of long-term negotiation and game. Even if members are still selected through consensus among member states, certain restrictions must be added. The country that voted against it should explain the specific reasons and propose a corresponding number of suitable candidates for selection.

\subsection{Summarizing Experience and Clarifying the Scope and Time Limit}

Member states need to summarize practical experience and clearly enumerate the review scope of the Appellate Body. For example, legal qualitative issues, legal issues caused by the wrong fact finding of the panel and unreasonable distortion of literal meaning, inferences. In addition, procedures for sorting out disputes can be introduced. When a party in the dispute files an appeal, the Appellate Body may clarify a specific fact or legal identification issue. If the party to the dispute cannot recognize the opinion of the Appellate Body, it shall submit a specific counter-argument within the prescribed time limit, and the Appellate Body may decide whether to adopt it. Or the DSU can add regulations that require both parties in the dispute to properly complete the fact finding in the panel report, and each party signs a "statement of fact" to facilitate subsequent independent review by the Appellate Body.

At the same time, member states can extend the time limit for the appeal process, such as specifying the 90-day time limit as working days (that is, excluding holidays, weekends and translation time.) Relevant MPIA regulations in this regard are also worthy of reference. For example, during the trial process, especially for complex cases, the Appellate Body should also estimate in advance how much time required. If the Appellate Body believes that more than 90 working days are required, it shall negotiate with the parties to the proceedings and apply for an extension. 


\subsection{Increasing the Readability and Relevance of the Appellate Body's Reports}

Regarding the Appellate Body's reports, member states can limit the number of pages of litigation documents. This will ensure that the Appellate Body does not express opinions on unrelated issues, thereby submitting "correct, clear and concise" reports.

If the Appellate Body interprets WTO legal agreements in the report, the WTO General Council and relevant councils should clarify them in a timely manner. This will ensure that the Appellate Body can adopt reasonable explanations in previous reports.

In addition, member states can jointly establish a communication channel between the Appellate Body and member states, such as regular exchange meetings. All member parties can express their opinions on certain related issues reported by the Appellate Body, and to a certain extent play a role in supervising the Appellate Body's report.

\section{CONCLUSION}

As the backbone of the international economic governance system, the WTO Appellate Body plays an important role in resolving international economic and trade disputes and protecting the fair and free development of international economic and trade. The original intention of the member states to jointly establish the Appellate Body is to get out of the practical difficulties encountered by the GATT dispute settlement mechanism in practice.

At present, the lockout of the Appellate Body indicates systemic and institutional problems, including the insufficient number of members, the unclear selection of judges and inappropriate voting rules. The scope of the appellate body's review is difficult to define, and the review period is too short. There are unnecessary discussions in the report, and its legal effect is not clear.

In this regard, it is suggested that people increase the number of members, clarify and refine the selection conditions for members, and modify the DSB voting rules to the majority voting rules. Second, it is necessary to standardize the scope of the appellate body's review, clarify how to distinguish between facts and legal issues in a case, and make general and exception provisions for the review period of the appellate body. Finally, the Appellate Body should limit legal interpretations and rulings to the extent necessary to resolve disputes. This article suggests that the WTO General Council and relevant councils should promptly clarify the interpretations of the WTO's legal agreements covered by the Appellate Body's report.

In addition, as a temporary measure taken by some member states during the suspension of the Appellate Body, MPIA can be seen as a powerful practice to promote the restoration of the normal operation of the Appellate Body. There is no "uncrossable gap" between MPIA and the WTO Appellate Body, that is, MPIA's full reference to the WTO Appellate Body system reflects the important value of the WTO Appellate Body. It is foreseeable that if the WTO Appellate Body continues to lockout in the future, many MPIA issues will also be put on the negotiating table. The important significance of MPIA is to reflect the consensus of the member states to maintain a fair and stable dispute settlement mechanism, which is also the most critical factor in reopening the WTO Appellate Body at the moment.

If member states want to solve the current problems of the Appellate Body, they need to be creative, and they need to cooperate and proceed from reality. Because if the reform only stays at the level of calling for cooperation between members rather than revising or improving the procedural rules for dispute settlement, the function of the dispute settlement mechanism may be more inhibited. At that time, the negative effects of the long-term suspension of the Appellate Body will be beyond our imagination.

\section{AUTHORS' CONTRIBUTIONS}

This article is independently completed by Yining Yang.

\section{REFERENCES}

[1] Appellate Body. Accessed on June 9, 2021. https://www.wto.org/english/tratop_e/dispu_e/a ppellate_body_e.htm

[2] Shaffer G , Elsig M , Puig S . The Extensive (But Fragile) Authority of the WTO Appellate Body. Social ence Electronic Publishing, 2016, p.241-242.

[3] Thomas Cottier, Marina Foltea. Constitutional Functions of the WTO and Regional Trade Agreements. Regional Trade Agreements and the WTO Legal System, 2006,pp59-60.

[4] The President of The United Ststes On The Trade Agreements Program. 2020 Trade Policy 
Agenda and 2019 Annual Report. Accessed on June 9 , 2021. https://ustr.gov/sites/default/files/2020_Trade_P olicy_Agenda_and_2019_Annual_Report.pdf

[5] Du Bo. WTO Dispute Settlement After the Appellate Body Ceases to Function. Nanjing University Law Journal, 2021, (1), p.105-107.

[6] LI Xueping. A Reflection on the Reform of WTO Procedural Mechanisms from the Perspective of International Law. Global Review 2019, (6), p.11-12.

[7] United States - Definitive Safeguard Measures on Imports of Wheat Gluten from the EUROPEAN COMMUNITIES, Appellate Body Report,WT/DS166/AB/R, 22 December 2000 para.150-151. ; Chile- Price Band System and Safeguard Measures Relating to Certain Agricultural Products, Appellate Body Report,WT/DS207/AB/R, 23 September 2002, para.224.

[8] Gilbert Guillaume, The Use of Precedent by International Judges and Arbitrators. Journal of International Dispute Settlement, Vol. 2, No. 1 (2012) p.6.

[9] Farewell speech of Appellate Body Member Yuejiao Zhang. Accessed on June 9, 2021. https://www.wto.org/english/tratop_e/dispu_e/y uejiaozhangfarwellspeech_e.htm

[10] China, EU and Other WTO Members Decide to Establish a Multi-party Interim Appeal Arbitration Arrangement. Accessed on June 9, 2021.

http://english.mofcom.gov.cn/article/newsreleas e/significantnews/202004/20200402951410.sht $\mathrm{ml}$

[11] MULTI-PARTY INTERIM APPEAL ARBITRATION ARRANGEMENT PURSUANT TO ARTICLE 25 OF THE DSU, article 2, 4-6. ANNEX 1, article 8, 10.

[12] Lester, S. (2020). Can Interim Appeal Arbitration Preserve the WTO Dispute System?. Cato Institute Free Trade Bulletin, 77(1). 